\title{
The Analysis of Inheritance Property Distribution in The Perspective of Minangkabau Customary Law and Islamic Law
}

\author{
Novi Asih Muharam ${ }^{1}$, Suparno $^{2}$ \\ \{novighezhaa@gmail.com¹, suparno@borobudur.ac.id² \\ Universitas Borobudur, Jakarta, Indonesia ${ }^{1,2}$
}

\begin{abstract}
Indonesia is a country with many ethnic groups that the cultural diversity and habits of its people also affect the norms formed in each ethnic group in Indonesia. In certain areas, people usually still use the prevailing customary law system. For example, the Minangkabau tribal community still adheres to Minangkabau customary law. First of all, it is essential to know the marriage system and the position in the kinship because the inheritance system in the Minangkabau indigenous people is essential before discussing further the division of inheritance in the Minangkabau indigenous people. In the Minangkabau indigenous people, the marriage system applied is called exogamous marriage and uses a matrilineal kinship system. Minangkabau's customary inheritance law contains two inheritance systems: collective inheritance for high inheritance and individual inheritance for low inheritance. The rules for the distribution of estate were based on meetings and seminars held in 1952 and 1968. Of course, the distribution of inheritance must be found on the principles, principles, and existing legal provisions to ensure legal certainty, benefits, and justice for the heir community.
\end{abstract}

Keywords: Inheritance; Minangkabau Customary Law; Islamic Law

\section{Introduction}

The distribution of control over property is different from the distribution of ownership of property.[1] Distributing the ownership of property means that have a movement of the wealthy from the estate owner to their heir, then the heir can control the property, but not own it. For example, the estate owner inherits a customary land to their heir. The heirs can usually hold or use the inherited traditional land but can't own the ancestral land.[2] Meanwhile, The transfer from ownership of the estate owners' assets to their heirs means that they have that inheritance fully. They are related to the heritage that is tangibly (material) and not intangible (immaterial), a substantial estate (material, which means that we can see and captured by our five senses, that inheritance such as a home, a land, a vehicle, etc. Then an intangible estate (immaterial). It means abstract property, which cannot be captured by the five senses, such as privileges, nobility, copyrights, patents, trademark rights, exploitation rights, trade secrets. And benefits or advantageous positions to generate income.[3] 
Thus, Western/Civil inheritance law is regulated in the KUH of Civil. Emphasize that when someone dies, they will distribute their inheritance to their heirs that are still left behind. Meanwhile, customary inheritance law regulates inheritance due to a person's death and holds how to distribute and transfer assets, whether tangible or intangible, whether it is worth or not worth money from the estate owner when he is still alive or has died to the heirs.

According to Ter Haar, customary inheritance law is the legal rules on how, from century to century, the transmission and transfer of tangible and intangible assets from generation to generation. So, the inheritance law contains three elements: the existence of inheritance assets, the existence of estate owner who leave assets, and the existence of heirs who will continue the management of the inheritance or who will receive their share of the inheritance. In customary inheritance law, inheritance is not a unit that can be valued as price but is a unit that is not divided according to the type and interests of the heirs. Customary inheritance assets may not be sold as a unit of the sales as money and then distributed to the community than to the heirs following the applicable provisions in Islamic Inheritance Law and Western Inheritance Law.[4]

Minangkabau is one of the most effective forms of matrilineal customary law communities in Indonesia. Minangkabau customary law is one of the established laws in Indonesia that must live and develop. According to maternal lineage, the Minangkabau community has a customary law from other ordinary law communities in Indonesia. This kinship will also determine a person's rights and obligations in the distribution of inheritance in friendly law communities. Because of that, on the one hand, there are often various criteria that can be used as the basis for these rights and obligations. In the Minangkabau community, Minangkabau customary inheritance law contains two systems: collective inheritance for high heirloom and respective heritage for the low artifact. Legacy with this collaborative system means that the inheritance is transferred from the estate owner to the heirs as a unit not divided into control and ownership. In Minangkabau, this system occurs on inherited property/land managed under Mamak Head of inheritance leadership. So, the members of the relatives have only the right to use it.[5]

According to maternal lineage, a high heirloom is inherited hereditarily from several generations (matrilineal). This property is divided into two-part, namely material property and moral property. Material Property, such as property from clearing for making rice fields, springs, ponds, gardens, gadang houses from ancestral businesses, are inherited from generation to generation as a high heirloom. High heirlooms in the form of morals are the titles of the people inherited from generation to generation, which are referred to as Sako custom. The members of the tribe themselves inherit a tall heirloom (Sako), that is, a woman. About inheriting customary's title of Mamak inheritance (brother of the mother) who inherited is his male nephew. On the other side, low heirlooms assets are all assets obtained from the results of their work. Usually, these everyday heirloom assets are inherited based on the provisions of the Islamic religion.

Islamic law has laid down the rules about distributing an inheritance and the law on property inheritance in the best and fairest way. Islamic law stipulates a person's property rights over property, whether male or female, through the syar'i way. Such as the transfer of property rights of men and women while still alive or transfer of property to their heirs after death. Islamic law does not discriminate between the rights of children and adults. The glorious Qur'an has explained the rules of inheritance and the provisions of each heir clearly and does not allow or limit a person's share of his inheritance rights.

The Qur'an is the basis and balance. The Sunnah and Ijma determine only a small part. In Islamic law, there are no laws that are described by the Qur'an as clearly and in detail as the 
law of inheritance. In Islamic inheritance law, it is explained that the division of inheritance in each party is entitled to its rights, contained in Qs. An-Nisa (4): 11 means:

Allah has ordained for you concerning (the division of inheritance for) your children. The share of one son is equal to the percentage of two daughters. And if the children are all women more than two, then for them is a quarter of the inheritance left. If the daughter is alone, then he gets half the inheritance. And for two people, parents for each a half of the estate left, if the deceased has children. If the dead has no children and is inherited by his parents (only), when his mother gets a quarter, his mother receives a half if the deceased has several siblings. (The above divisions) after the fulfillment of the will he made or (And) after the debt is paid, (As for) your parents and your children, you do not know which of them is nearer (much) in benefit to you. There is a decree from God. Indeed Allah is Knowing and Wise.

Although the authorities do not sanction this Islamic law, it is obeyed by the Islamic community because of their awareness and belief, especially the thought of Islamic leaders or scholars, that Islamic law is the proper law. in a copy of Islamic Law.[6] The relationship between customary and Islamic law in the sense of "contact" between the two systems has long existed in Indonesia. The association is close in society. This familiarity is reflected in various proverbs and expressions in several regions. For example, the phrase in the Aceh language reads on adat law, phantom center, lagee zat ngon sipeut. Goods or objects. In Minangkabau custom which is reflected in the proverb: adat and syara, sanda mennyanda, syara mengato adat wear.[7] According to Hamka the meaning of this proverb is the relationship (law) of adat with Islamic law (syara) is very close, mutually supporting each other, because, what is called adat, which is genuinely custom, is syara itself. In this relationship, it is necessary to explain that adat in this expression is a way of implementing or using the syara ${ }^{\text {ee }}$ in society. [8]

The existence of adat and syara in Minangkabau cannot be separated, which is described philosophically by the presence of aur and cliffs, which need each other and cannot be separated from one another. There is called the scientific term "Mutualist Symbiosis." "Aua," which means "air," is a kind of yellowish bamboo plant. Naturally, the growth of the cliff, which in Minang language is called "tabiang," cliffs is needed by the aur for a place to grow, and vice versa aur is required by cliffs to hold the ridge from collapsing.

Inheritance law in Minangkabau society is carried out collectively, while Islamic law implements it individually. In the normative that Islamic inheritance law and Minang customary inheritance law, it is seen that the two applicable legal systems contradict each other. There is understandable because the conflict theory they used to approach the problem of the relationship between the two legal systems was consciously used to divide and pit the Indonesian people against each other to strengthen Dutch power in Indonesia.[9] Therefore, the attitude of the colonial rulers towards the two legal systems can be likened to the perspective of a person splitting bamboo, lifting one part (custom and suppressing the other (Islam), this attitude is clearly illustrated in one of the sentences by Van Vollenhoven [10], an expert on customary law. He was famous when he had a polemic with his government regarding the legal politics implemented in the Dutch East Indies. According to van Vollenhoven, customary law must be maintained as law for the Bumiputera group, and it should not be forced by western law. Because if customary law is urged (by Western law), Islamic law will apply. There should not happen in the Dutch East Indies.

\section{Methods}


Based on the background of the problem, the problem can be put forward; what is the analysis of Islamic law on Minangkabau customary inheritance? In this journal, the research method used the rational approach. The sensible way will be used by searching from reference articles from journals, books and looking for data on websites to complete this writing material.

\section{Discussion}

Minangkabau is one of the major ethnic groups in Indonesia, such as Sundanese, Javanese, Madurese, etc. Minangkabau ethnic groups tend to migrate, especially to Minangkabau men. To meet Minangkabau people in various parts of Indonesia in particular and in other parts of the world. In Minangkabau culture, heirlooms are divided into two parts, namely high inheritance, and low inheritance

Article 830 states, "Inheritance only takes place because of death." So the inheritance is only opened if the heir has died while the heirs are still alive when the estate is open. In this case, there is a special provision in Article 2 of the Criminal Code, namely that a child in the womb of a woman is considered to have been born if the child's interests so desire. Dying at birth is presumed he never existed. A child born when his father died was entitled to an inheritance. This is regulated in Article 836, "taking into account the provisions in Article 2 of this book, to act as an heir, a person must be present at the time the inheritance falls to them".

Islamic inheritance law is a law that arranges everything related to the transfer of rights and obligations over a person's inheritance after he died his heirs. Islamic inheritance law is also called fard law which means a responsibility that must be carried out. The source is the Qur'an, especially the letter An-Nisa '(4) verses 11, 12, 176 and, Al-Hadith which contains the Sunnah of the Prophet which was then developed in detail by Islamic jurisprudence experts through the ijtihad of qualified people, according to space and time. The situation and the conditions of the place of ijtihad. In (a) paragraph 7, it is emphasized that a man has the right to inherit his father and his mother, likewise with women. She has the right to inherit from her parents. In paragraph 11, it is emphasized that girls have the right to inherit from their parents as well as boys, with the ratio of the share of a boy being as much as the percentage of two girls, the mother has the right to inherit from her child, both male, and female by a half. Same as the father, he has the right to receive an inheritance from his child, both male, and female, in the amount of a half, if the estate owner leaves the child. In verse 12, it is explained that if a man dies of extinction, his male brother will get the inheritance; his female brother is also entitled to his estate. Women are entitled to receive their inheritance. In Surah An-Nisa (4) verse 176, it is stated that a man who has no offspring, while he has a sister, then his sister is the one who is entitled to receive his inheritance. A woman who has no children, while she has a brother, her male brother is entitled to receive her inheritance.

According to Minangkabau custom, the inheritance acquired by a clan or one of its family in any way, after being handed down once, the property will join itself with the estate received from the previous generation. For example, a person who gets an inheritance from the results of his own business deserves to benefit from the legacy for his benefit with his children and grandchildren.[11] But if he has died and his heirs do not unequally share the inheritance, then the property will be combined with a high heirloom. The low artifact will change its function into a tall heirloom. There can repeatedly happen and from generation to generation so that each generation of quiet heirloom treasures will mingle continuously with high heirloom treasures. 
The Minangkabau customary inheritance law must be based on standard rules that have been agreed upon by the scholars and the adat, namely " established syara tradition and syara basandi Kitabullah Al-Qur'an," that is, Minangkabau customary inheritance law is Islamic inheritance law itself, it cannot be interpreted otherwise. However, in the past colonial era, especially Dutch colonialism, they made a theory of customary law known as the "reception theory," which annulled Islamic inheritance law.

In the second period, there was equality of tradition with Islamic teachings called syara. There can be proven with a government system in Minangkabau, especially since King Pagaruyung was already a Muslim, Sultan Alif, who died in 1580 (the next successor is unknown). Along with the king of worship, the development of Islam is getting better in Minangkabau, both in terms of education, law, and religion. Culture, including in direction, the Syar'iyah Court appeared in Minangkabau to solve Syara law.[12]

\subsection{Matrilineal System}

Hazairin said that the Minangkabau people have different ways of determining family. Every man and woman draw their lineage upwards only through the female line as a blood channel. That is, each person draws their heritage to their mother and from their mother and grandmother, and so on. According to the patrilineal line system, a man does not have descent who becomes his family. Although.[13]

the man is considered to have no defeat in his people, he is called a Mamak. This system causes him to be fully responsible for maintaining his nephews and the wealth of the people inherited from generation to generation by the mother's family. As the heir's head, Mamak must take care of people's assets such as ulayat and land, he is obliged to take care of the inheritance properly, but to sell or pawn him, he is not allowed. Mamak and nieces seem closer than father to son. The characteristics of the Minangkabau people with the matrilineal system are as follows:[5]

1. descendants are calculated based on the mother's lineage

2. Tribes are formed according to the matrilineal line

3. Everyone is not allowed to marry someone from their ethnic group, or they must marry someone outside their tribe (exogamy)

4. In theory, the power within the tribe rests with the mother, but it is rarely used because, in practice, it is the mother's brother who has the power.

5. Marriage is matrilocal. That is, the husband visits his wife's house.

6. Mamak passes on rights and inheritance to his family to his brothers $t \backslash$ or daughters.

\subsection{Patrilineal System (Father Line Group)}

The hereditary system is drawn according to the father's line, where the position of men is more prominent than the position of women in inheritance. In a patrilineal society, the dissolution of marriage due to death and divorce does not change the responsibilities of the husband's family/relatives towards the children and wives of family/household members descended from father, grandfather, and so on. So when a marriage breaks up due to death or divorce, the children remain with their father's relatives. If the marriage is dissolved due to divorce, the wife must leave the husband's house without rights except for her private inheritance.

\subsection{Parental or Bilateral System (Mother-Father Line Group)}


A system has drawn according to the line of parents, or according to the line of two sides of the father-mother where the position of men and women is not distinguished in inheritance. In the parental community, if there is a termination of marriage due to death, the children will follow the parents who are still alive. If divorced, personal property returns to each other, while the joint property is between them.

The development of the community which on behalf of the land that he owns and make the name of his son. So the ground is not confessed by the tribe or their big family. There happens because the Minangkabau people are already aware of their obligations to their families, and they are trying to get out of existing customary regulations. So that with this, there was a development of various kinds of property owned by the Minangkabau family where there was a separation between the rights inheritance of a large family or tribe with the heritage of a small family. Many of these things were done because several cases caused people had been expelled from their homegrown. Sutan Kurnia Alam experienced this case.

He was a wealthy merchant because his relationship with his wife was well maintained, and he already had a son, so he built a pusako house for his wife. After his wife died, he was forced to migrate with his children because, according to custom, he could no longer live in that house. The house returned to the tribe. Therefore, the course makes the Minangkabau people aware that their efforts will only add to the tribe's heritage. Then after Islamic law entered Minangkabau society, many people used Islamic law, but only to the extent of their assets, not disturbing the position of tribe heritage.

Previously, it was explained that all existing property would become heirlooms. However, after Islam entered the Minangkabau region, there was sorting of inheritance. According to tradition, the property is inherited by Mamak to their relatives. According to Islam, the property is inherited by children. There caused Minangkabau fathers to donate their property to their children during their lifetime, so the child will have it when the father dies. They do it to their relative do not think they deserve the inheritance of their Mamak.

The acquisition of heirs also needs to be investigated how much the parents use the heirloom used for their own business. After separating the antique used, then the property can be distributed according to the applicable provisions. The artifact used must be given according to a custom; meanwhile, their wealthiness will be shared with Syara law. Minangkabau's tradition can accept various ways that had been done to make Islamic law. However, in reality, Islamic law can be well received and even strengthens the position of Minangkabau's custom. There is proven by the Minangkabau people, who are still thick with Islamic teachings. Then, the inheritance became the hallmark and dignity of the Minangkabau tribe, even after Islam existed. Its position is getting clearer where the legacy remains with the tribe with the opinion of the Minangkabau cleric who punishes the property with mussabalah property, and the property is left to Islamic law. There is essential to do so that there will be no struggle between the Minangkabau families where there are mutual claims to existing assets in subsequent developments. In addition, with the separation, the Minangkabau community can develop their own business because their heirs can use the property. Suppose the heirs do not share it with existing Islamic law. In that case, the parents' inheritance will become the family's heirloom property which can be used to benefit the family or the next generation.

\section{Conclusion}

Based on the discussion about the distribution of inheritance to the Minangkabau's people, it can be concluded several things as follows: 
The division of inheritance in Minangkabau customs is divided into:

1. Legacy of low heirloom controlled by a smaller family, consisting of a wife and children, or a husband and his siblings and the descendants of the identical sister.

2. Inheritance of high heirloom controlled by a more prominent family or relatives led by an Andiko or Mamak, the head of a legacy.

3. The factors that cause changes in the distribution of inheritance include the influence of Islam, the economy, education, and the environment. Obedience and obedience to religion cause customary law to be ruled out. Economic needs are also the main thing to consider in continuing family life so that these changes occur. Educational factors affect because of the increased knowledge of the rights and obligations that will be owned. Environmental factors, which are overseas areas that cause customary law, cannot be used.

In the distribution of inheritance, the Minangkabau community is expected to be firm in choosing to be guided by the compilation of Islamic Law (Faraidh) or based on mutual agreement. Therefore, apply it thoroughly, both in terms of who gets it from gender, whether in the number of parts or when the inheritance is divided. It is hoped that there will be no delay in the distribution of estate so that disputes do not occur in the future. It is hoped that the Minangkabau community will deepen its knowledge of Islamic customs and inheritance law. It is expected that the Minangkabau community will get used to immediately using the services of a notary in making the distribution and separation of inheritance. The distribution of inheritance that requires registration is directly made before a notary so that there is legal force.

\section{References}

[1] Z. Zahroni and F. Santiago, "Ulayat Rights in A Human Rights Perspective," in ICLSSEE 2021, 2021, pp. 3-8, doi: 10.4108/eai.6-3-2021.2306456.

[2] E. E. Supriyanto, "Politik Kebijakan Ketahanan Pangan Indonesia Pasca Pandemi Covid-19," in Pertanian Dalam Ketahanan Pangan Selama dan Sesudah Covid-19, vol. 1, no. 1, Denpasar: Penerbit Yayasan Guna Widya Paramesthi, 2021, pp. 33-43.

[3] A. Suntoro, “ASSESSMENT OF COMPENSATION IN LAND ACQUISITION FOR PUBLIC INTEREST : HUMAN RIGHTS PERSPECTIVE,” BHUMI J. Agrar., vol. 5, no. 1, pp. 13-25, 2019.

[4] M. Žgur, "The law and politics of inclusion. From rights to practices of disidentification," Jurisprudence, vol. 12, no. 2, pp. 308-315, 2021, doi: 10.1080/20403313.2021.1874728.

[5] Y. N. Winstar, "Pelaksanaan Dua Sistem Kewarisan Pada Masyarakat Adat Minangkabau," J. Huk. Pembang., vol. 37, no. 2, p. 154, 2017, doi: 10.21143/jhp.vol37.no2.1483.

[6] A. Yani and M. Barthos, "Transforming Islamic Law in Indonesia from a Legal Political Perspective," Al-Ahkam, vol. 30, no. 2, pp. 159-178, 2020, doi: 10.21580/ahkam.2020.30.2.6333.

[7] Z. Wimra, "Reintegrasi Konsep Maqashid Syari'Ah Dalam Adat Basandi Syara', Syara' Basandi Kitabullah," JURIS (Jurnal Ilm. Syariah), vol. 15, no. 2, p. 191, 2017, doi: 10.31958/juris.v15i2.499.

[8] S. Tono, M. R. Syibly, A. Mu'allim, A. Nurozi, and M. R. Purwanto, "The harmonious relationship between minangkabau custom and Islam in the distribution of inheritance," Al-Shajarah, vol. 2019, no. Special Issue Sharia hand Law, pp. 39-55, 2019. 
[9] L. Arliman, "Hukum Adat Di Indonesia Dalam Pandangan Para Ahli Dan Konsep Pemberlakuannya di Indonesia," J. Selat, vol. 5, no. 2, pp. 177-190, 2018, doi: 10.31629/selat.v5i2.320.

[10] C. Van Vollenhoven, J. F. Holleman, and H. W. J. Sonius, Van Vollenhoven on Indonesian adat law. Springer, 2013.

[11] W. Azwar, Muliono, Y. Permatasari, H. Akmal, S. Ibrar, and Melisa, "Nagari Customary Justice System in West Sumatra," J. Bina Praja, vol. 11, no. 1, pp. 53-62, 2020, doi: 10.21787/jbp.11.2019.53-62.

[12] T. Abdullah, Adat and Islam: An Examination of Conflict in Minangkabau, vol. 2. Cornell University Press, 1966.

[13] M. Syakroni, "Pemikiran Kewarisan Bilateral Hazairin," Sosio-Religia, vol. 8, no. Khusus, 2009. 